\title{
Study proposes PhD reforms, but no quota
}

Washington. The US system for educating graduate students is the best in the world and is not in need of drastic repair, despite a recent wave of complaints from young scientists, according to a report from the National Academy of Sciences.

The report, prepared by the academy's Committee on Science, Engineering and Public Policy (COSEPUP), suggests new block grants to support graduate students, and more intensive career guidance. But it rejects any effort to limit the number of students embarking on PhDs, or to restrict the number of foreigners amongst them.

Phillip Griffiths, director of the Institute for Advanced Study at Princeton University, New Jersey, and chairman of the committee, says that the $\mathrm{PhD}$ system is not in crisis, and that its problems are more subtle than is often supposed. "We were prepared to be more radical," says Griffiths. But after listening to the people involved and studying the data, the panel "couldn't agree with the people who say the sky is falling".

Before the panel began its work, says Griffiths, "we thought PhDs were not getting jobs. They are, and they're not driving taxis." The panel found that most PhDs who failed to find academic posts eventually prospered in other sectors. "But the transition can be painful, and nobody has been telling the students to expect it," he says.

Those who have been emphasizing the difficulties faced by $\mathrm{PhDs}$ in finding suitable academic positions are disappointed with the findings. "The report is little more than a collection of platitudes", says Bob Park, director of public affairs at the American Physical Society. "Everyone knows there's a problem, and all they've done is restate it, without offering any solution."

The academy recommends a national effort - including a database kept by the National Science Foundation - to provide better guidance on "realistic career options" for graduate students. It also suggests that government agencies and private foundations should provide new, block grants to fund education and training at universities and departments.

These would directly support students doing PhDs, alleviating their customary reliance on research assistantships. The panel says such direct support would help to shorten $\mathrm{PhD}$ courses and strengthen their educational component.

Finally, the report calls for a more flexible $\mathrm{PhD}$ structure to allow students who are not planning a career in academic research to take at least two alternative "pathways" to the traditional $\mathrm{PhD}$. One would end with a master's degree, while the other would offer a full $\mathrm{PhD}$, combining more taught content with a shorter dissertation.

The academy rejects capping the number of PhDs awarded in the United States. There are now 25,000 each year and the number is growing. More $\mathrm{PhDs}$ are useful to the nation, it argues, and capping would in any case be ineffective in the short term, hard to orchestrate, and insensitive to the unpredictable variance in demand for $\mathrm{PhDs}$ in different fields.

Rejecting limits on foreign students, the panel argues - simultaneously and paradoxically - that the best stay, strengthening the US economy, and that improving economic conditions in students' home countries will encourage most to return.

The report is, in effect, the science establishment's official response to a growing wave of anger from young scientists who find themselves trapped in low-paid, postdoctoral positions, unable to get permanent work in academic research.

Zachary Levine, recently elected to the council of the American Physical Society on this issue, says: "There are 700 jobs each year for physicists in academic research and 1,400 people heing trained to fill them. We either need to cut down the number of PhDs or work out how to place them in non-academic settings."

Colin Macilwain

\section{Now chemists hit at Smithsonian's 'anti-science' exhibit}

Washington. Leaders of the American Chemical Society (ACS) will meet officials of the Smithsonian Institution in Washington within the next few days to agree on a procedure for changing the Smithsonian's Science in American Life exhibition to meet criticism that it has an anti-science bias.

The ACS has also criticized the Smithsonian for listening to the objections of "vocal groups" who had no responsibility for the exhibition. This is a veiled reference to recent protests by the American Physical Society (APS), which has publicly accused the show of exaggerating science's failures and trivializing its accomplishments (see Nature 374, 207; 1995).

The meeting was arranged after the ACS - which provided $\$ 5.53$ million to sponsor the show - broke almost a year of silence and launched a vehement attack on both its content and the consultative process leading up to its design.

According to a letter sent on 21 February from Paul Walter, chairman of the society, to Michael Heyman, secretary of the Smithsonian, the four years spent planning the show were a source of "constant frustration" to ACS officials.

"Smithsonian staff consistently ignored the advice given them by an advisory board we jointly put together," wrote Walter. "We expected the opportunity to negotiate; what we received was one rebuff after another. Arrogance and high-handedness too often

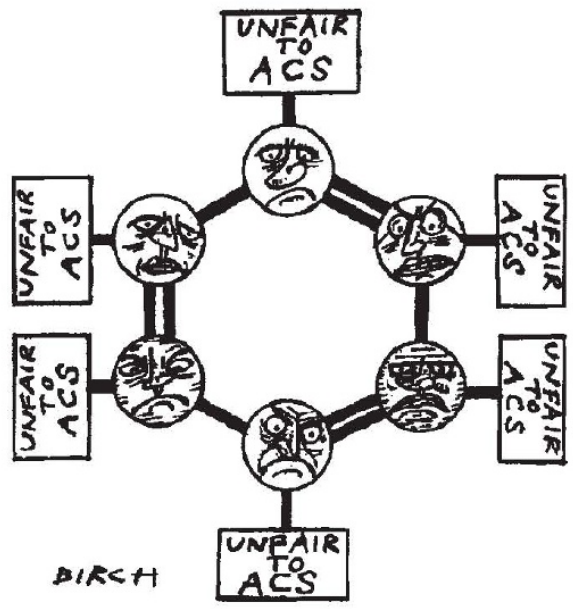

characterized the behaviour of some of the museum personnel assigned to this project."

The letter echoes criticisms made last year by the APS. It says that parts of the exhibition "demonstrate a strong built-in bias against science and display a tendency to revise and rewrite history in a "politically correct' fashion".

Without naming the APS, the letter implicitly attacks the rival group for its role in publicly criticizing the exhibition and proposing changes to it. "We have learned that individuals or groups who had little or nothing to do with the design and planning of the exhibit, and who made no financial contribution to it, may now expect to play some major part in its redesign," it says.

"Frankly, we worry that the Smithsonian Institution, beset as it is by public and Congressional criticism, may be tempted to make changes based on just the views of the most vocal groups presenting themselves at your doorstep."

According to Walter, the planned meeting of four senior ACS officials with four Smithsonian officials, including Heyman and the exhibition curator, Art Molella, will ensure that both sides will fully support any agreed process to modify the show. The chemical society has set up a five-member task force, chaired by Joan Shields of Long Island University, New York, to work with the Smithsonian on that process.

Ned Heindel of Lehigh University, Bethlehem, Pennsylvania, a member of the task force and a past president of ACS, promises that the chemists' group will consult the physicists during the process. "It doesn't benefit either of us to be in an arm-wrestling match over this," he says.

C.M. 